
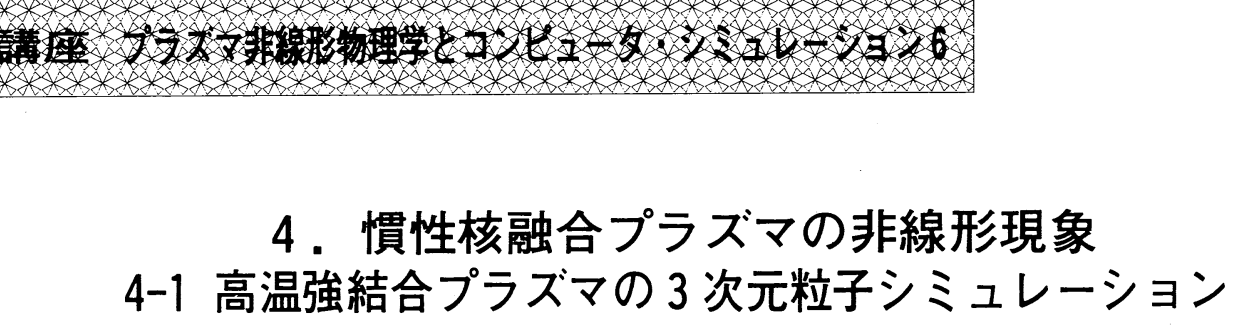

西 原 功 修

(大阪大学レーザー核融合研究センター)

(1991年8月19日受理)

\title{
3D Particle Simulation of Hot Dense Plasma
}

\author{
Katsunobu Nishihara
}

(Received August 19, 1991)

\begin{abstract}
Presented is a 3D particle code SCOPE which has been developed to simulate a large scale two component strongly coupled plasma. The code uses the 4 th order in accuracy particle-particle particle-mesh method. As applications of the code the reduction in bremssthrahlung emission from a hot dense plasma and the nonlinear AC electric conductivity of a solid density plasma are shown.
\end{abstract}

Keywords :

two component strongly coupled plasma, hot dense plasma, particle-particle particlemesh code, pair distribution function, bremsstrahlung emission, nonlinear electric conductivity,

1.はじめに

ミニ太陽の実現を目指す慣性核融合プラズマ は，図１に示すように，その密度と温度のパラ メータ一領域は非常に広範囲に及んでいる。燃焼 プラズマはまさに太陽中心と同程度の密度と温度 である。このプラズマは理想プラズマ(弱結合プ ラズマ) であるが，圧縮に要するエネルギーを少 なくするにはできるだけ低い温度で圧縮する必要
があり，圧縮過程においては，近接粒子間のクー ロンポテンシャルエネルギーと粒子の運動エネル ギーが同程度の強結合プラズマが実現する。また， 電子の運動エネルギーもフェルミエネルギーと同 じ程度であり，電子もイオンもお互いに強い相関 関係を持ちながら運動することがその特徵である． この様なプラズマを 2 成分強成分プラズマ ${ }^{1)}$ と呼 ぶが，天体は別として，これまで実験室では実現

Institute of Laser Engineering, Osaka University, Suita 565. 


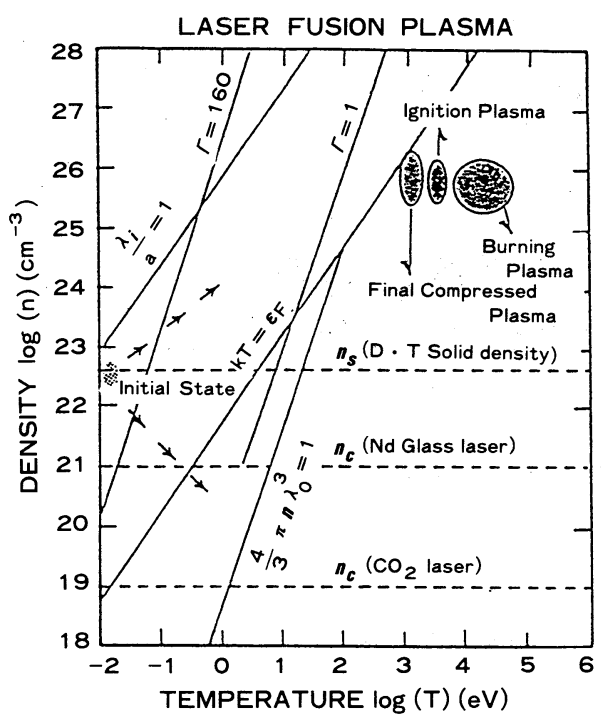

図 1.レーザー核融合プラズマの温度と密度.

できなかった高温度の強結合プラズマ状態であり， 慣性核融合の実現だけでなく，広く物理的に興味 のある分野である。

高密度プラズマの特性は 2 つのハラメーターに より決定される。近接イオン間のクーロンポテン シャルエネルギーと運動エネルギーの比,

$$
\Gamma=\frac{z^{2} e^{2}}{a k T}, \frac{4}{3} \pi a^{3}=\frac{1}{n_{\mathrm{i}}}
$$

ここで, $n_{\mathrm{i}}, T, e, z$ はそれぞれイオン数密度, 温度, 電荷, イオンの電荷数である。 $a$ と $\Gamma$ はイ オン半径とイオン結合係数という．イオン結合系 数はプラズマパラメーター $\left(n \lambda_{D}{ }^{3}\right)^{-1}$ の3/2乗に比 例する。ただし， $\lambda_{\mathrm{D}}$ はデバイ長。理想プラズマ ではイオン結合係数は 1 より十分小さく，個々の 粒子間のクーロン相互作用は無視できる。一方, 高密度プラズマではイオン半径が小さくなり集団
的な振舞いだけでなく個々の粒子間の相関も重要 となる。もう 1 つのパラメー夕は電子縮退パラ メータであり，運動エネルギーと電子のフェルミ エネルギーの比

$$
\theta=\frac{k T}{\varepsilon_{F}}, \quad \varepsilon_{F}=\frac{h^{2}}{2 m_{\mathrm{e}}}\left(3 \pi^{2} n_{\mathrm{e}}^{2 / 3}\right)
$$

ここで, $h, n_{\mathrm{e}}, m_{\mathrm{e}}$ はそれぞれプランク定数, 電 子数密度, 電子質量である. $\theta<1$ の状態では電 子は縮退しており，イオンの運動のみが重要とな る（1成分強結合プラズマ）が $\theta>1$ では電子の 運動をも考慮しなければならない。この章では,

$$
\Gamma \sim 1 \sim 10, \quad \theta \sim 1 \sim 10
$$

の 2 成分強結合プラズマを対象とする。この様な 2 成分強結合プラズマの性質については, 特にダ イナミックスについては理論的方法はまだ確立し ていない1).さらにシミュレーションについても 少数の粒子を扱った試みがあるだけであり ${ }^{2)}$ ，大 きな系を扱った例はない．

良く知られているように，理想プラズマ（無衝 突プラズマ）の粒子シミュレーションでは, 個々 の粒子間力を抑制することが重要であり，有限の 大きさの粒子や空間格子が導入されてきた ${ }^{3)}$ 。一 方，個々の粒子間力を計算する手法として分子動 力学的手法 ${ }^{4)}$ が開発されてきた。対象とするプラ ズマのダイナミックスを調べるにはいずれの手法 も不十分である。本学会誌ではこの様な問題は扱 われたことがないので, 本講座の他の章とは趣を 異にするが手法についても少し詳しく述べたい． 


\section{2. 高精度 2 成分強結合プラズマ粒子コード $\lceil S C O P E\rfloor$}

イオン結合係数と電子縮退パラメーターがそれ ぞれ $\Gamma \sim 1, \theta \geqq 1$ である電子 -イオン 2 成分強 結合プラズマのダイナミックスを取り扱える 3 次 元粒子コード「SCOPE」（Strongly COupled plasma ParticlE code）を紹介する ${ }^{5)}$ 。この様なパ ラメーターの強結合プラズマでは近接する個々の 粒子間に働く力が重要であるばかりでなくクーロン 力による長いスケールでの集団的な振る舞いも重 要となっている. 従って, この様なパラメーター 領域の大規模な粒子シミュレーションは非常に困 難である。この困難を解決する手法としてPPPM (Particle-Particle Particle-Mesh) 法が Hockney, Eastwoodにより提案された ${ }^{6)}$. PPPM法では近接 の粒子間力あるいは近距離力は, 分子動力学のシ ミュレーションで行うように個々の粒子間力を加 算し（PP 法），十分遠くの粒子間力あるいは長距 離力は, 無衝突プラズマ粒子シミュレーションで 行うように，粒子一格子法（MP 法）を採用する.

例えば，図 2 に示すように空間を格子に分割し， 図中の $i$ 粒子に働く他の粒子からの力を次の $2 つ$ に分けて計算する。ハッチ領域（以下，簡単のた め $\mathrm{PP}$ 領域と呼ぶ）にある $j_{1}, j_{2}$ 粒子からの 力は粒子間距離を用いて直接計算し，また，八ッ チ領域外にある $j_{3}$ 粒子からの力は, 粒子電荷を 格子点上に割付け, 格子点で定義される電荷分布 からポアソン方程式（差分方程式）を解き電場を 計算し， $i$ 粒子にその電場を割り付ける。全ての 粒子間力を直接計算する従来の分子動力学的手法 では計算時間が粒子数の 2 乗に比例して増大する がPPPM 法では本質的には粒子数に比例した計算時

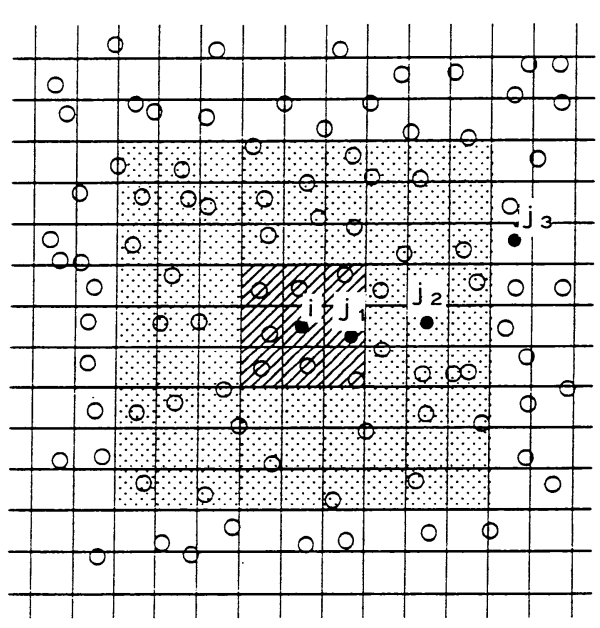

図 2.3 次元強結合プラズマ粒子コード「SCOPE」 における PP (particle-particle) 領域とPM (particle-mesh) 法の空間格子. 斜楾領域の 粒子 $i$ の運動方程式を解く場合に, 斜線領域 と点領域 (PP 領域) にある $j_{1}, j_{2}$ 粒子か らの力は粒子間距離を用いて計算し, PP 領域 外にある $j_{3}$ 粒子からの力は空間格子を用い た PM 法で計算する.

間でよく，しかも近接粒子間力を取り込むことが 出来る。その結果, 大きな空間スケールのプラズ マの長時間シミュレーションが可能となる.

$\mathrm{PP}$ 領域の大きさは近距離力（詳細は後述する) のおよぶ距離で決定され，PM 法で用いる格子の大 きさはPM 法の解法で決まる精度（詳細は後述す る）により決定する。しかしながら，PP 法と PM 法との接続の問題, あるいは空間格子の大きさと 精度の関係についてこれまで詳細な解析がなされ ていなかった。

PM 法では格子上の電荷を用いて格子上の電場を 計算するが，その時 PP 領域内の粒子の寄与が含 まれてしまう。それを取り除かなければならない， 接続の問題は具体的にはPM 法で求めた電場から $\mathrm{PP}$ 領域内の粒子の電荷の寄与を取り除く問題であ る。またPP領域の大きさと PM 法の格子の大き 
さとの関係は 2 次精度の割付法と 2 次精度の差分 については調べられている7) が, 高精度のものに ついては明らかでない.

高精度の割付法と差分法を導入することにより， 従来の方法に比べ十分少ない格子数で高精度のシ
ミュレーションが可能となることを示そう。必要 な格子数の減少により計算時間が短縮され長時間 のシミュレーションが可能となる.

非常に近傍した粒子間力を扱うためにここで はDeutschにより導入されたポテンシャルを用い $ろ^{8)}$. 具体的な粒子間力は電子一電子間では,

$$
\boldsymbol{F}_{\mathrm{ee}}=\left\{\frac{e^{2}}{r^{3}}-\frac{e^{2}}{r^{3}}\left(1+\frac{r}{\boldsymbol{\pi}_{\mathrm{ee}}}\right) \exp \left(-\frac{r}{\boldsymbol{\pi}_{\mathrm{ee}}}\right)+\frac{2 k T}{\pi \boldsymbol{\star}_{\mathrm{ee}}^{2}} \exp \left(-\frac{r^{2}}{\pi \ln 2 \boldsymbol{\star}_{\mathrm{ee}}^{2}}\right)\right\} \boldsymbol{r}(4)
$$

電子ーイオン, イオンーイオン間では

$\boldsymbol{F}_{\alpha \beta}=\left\{\frac{q_{\alpha} q_{\beta}}{r^{3}}-\frac{q_{\alpha} q_{\beta}}{r^{3}}\left(1+\frac{r}{\boldsymbol{x}_{\alpha \beta}}\right) \exp \left(-\frac{r}{\boldsymbol{x}_{\alpha \beta}}\right)\right\} \boldsymbol{r}$

を用いる。ここで $\boldsymbol{r}$ は粒子間距離, $e, q_{\alpha, \beta}$ は 電子の電荷, 電子またはイオンの電荷である. $\lambda_{\alpha \beta}$ は熱的ド・ブロイ波長,

$$
\star_{\alpha \beta}=\frac{\hbar}{\sqrt{2 \pi \mu_{\alpha \beta} k T}}
$$

また， $\mu_{\alpha \beta}$ は換算質量

$$
\mu_{\alpha \beta}=\frac{m_{\alpha} m_{\beta}}{m_{\alpha}+m_{\beta}}
$$

である. 式(5)の第 1 項, 第 2 項, 第 3 項は, それ ぞれクーロン力, 量子的ゆらぎの効果（トンネル 効果), 対称性の効果（パウリの排他性）である ${ }^{8)}$. (4)，（5）式から明らかなようにこのモデルでは短 距離力は電子の熱的ド・ブロイ波長で決まってお り, 熱的ド・ブロイ波長より長い距離では指数関 数的に減少する. 従って PP 領域の大きさ $\Delta_{\mathrm{pp}}$ は
熱的ド・ブロイ波長より十分大きくとればよい. 例えば $\Delta_{\mathrm{pp}} \sim 6.5 \lambda_{\alpha \beta}$ とすればクーロン力とのず れは $1 \%$ 以下となる。なお縮退パラメーター $\theta$ は, 熱的ド・ブロイ長と電子球半径との比を用いると

$$
\theta=\left(\frac{27}{3^{4} \pi^{5}}\right)^{1 / 3}\left(\frac{a_{\mathrm{e}}}{\boldsymbol{x}_{\mathrm{ee}}}\right)^{2}, a_{\mathrm{e}}=\left(\frac{3}{4 \pi n_{\mathrm{e}}}\right)^{1 / 3}=\frac{a}{z^{1 / 3}}
$$

となり, $a_{\mathrm{e}} \gg \pi_{\mathrm{ee}}$ は $\theta>1$ の条件となる.

PP 領域の大きさが熱的ド・ブロイ波長に比べて 十分大きい場合には，PP 領域外の粒子からの力は クーロンカだけとなり, 無衝突プラズマシミュ レーションに用いられるCIC 法 (PIC 法とも言 う）等が適用できる ${ }^{3)}$. CIC 法では, 格子の大き さと（セルとも言う）と同じ大きさの一様な荷電 分布を持つ粒子を考え, 粒子電荷の格子点への割 付, および格子点上の電場の粒子上への割付に線 
形補間を行う。CIC 法は 2 次の精度を持つ. CIC 法ではポアソン方程式, 拉よびポテンシャルの勾 配の計算には 2 次精度の差分法がよく用いられる。 差分方程式は, 例えば周期境界条件の場合には高 速フーリエ変換(FFT：Fast Fourier Transform) がよく用いられる。具体的には格子点 $x_{l}$ での電 荷密度は, 格子の大きさを $\Delta$ とし粒子位置を $x_{i}$ とすると，

$$
\rho_{l}=\sum_{i} q_{i} \int S\left(x-x_{\mathrm{i}}\right) W\left(x-x_{\mathrm{i}}\right) \mathrm{d} x
$$

から計算する。ただし， CIC 法では形状因子 $S$ $(x)$ と重み関数 $W(x)$ は

$$
\begin{aligned}
S(x) & =1, \quad|x| \leq \frac{\Delta}{2} \\
& =0, \quad|x|>\frac{\Delta}{2} \\
W(x) & =1, \quad|x| \leq \frac{\Delta}{2} \\
& =0, \quad|x|>\frac{\Delta}{2}
\end{aligned}
$$

となる。（9),（10）式の 3 次元への拡張は容易で ある。以下記述の簡略化のため 1 次元表示とする。 また格子点上の電場 $\boldsymbol{E}_{l}$ から粒子に働く電場への 割付も同様に

$$
\boldsymbol{E}_{i}=\sum_{l} \boldsymbol{E}_{l} \int S\left(x-x_{i}\right) W\left(x-x_{l}\right) \mathrm{d} x
$$

から計算できる。
2 次の差分方程式は

$$
\begin{aligned}
& \nabla^{2} \phi=\frac{\phi_{l+1}-2 \phi_{l}+\phi_{l-1}}{\Delta^{2}}=-\rho_{l} \\
& \boldsymbol{E}=-\nabla \phi=-\frac{\phi_{l+1}+\phi_{l-1}}{2 \Delta}
\end{aligned}
$$

となる。

よく知られているように，有限の大きさの粒子 の導入と格子点の導入は非物理的な力を生む ${ }^{3)}$. クーロン力との誤差は粒子間隔 $\Delta$ で規格化した 2 粒子間の距離と粒子の格子点に対する相対位置に 依存する。1つの粒子がセルの中心にあり，他の 粒子を格子と平行に移動させた場合の CIC 法で 求めた力とクーロンカとの誤差を図 3 (a) の破線で 示す．距離 $x / \Delta \leqq 1.5$ での大きな誤差は有限の大 きさの粒子の導入に起因し，格子間隔の整数倍で 生じる振動は割付の線形補間による。誤差は距離 の 2 乗に逆比例して減少するが図 3 (a) からも明ら かなように，格子間隔で規格化した距離が13以下 では $1 \%$ 以上の䛊差が生じる。

従って，例えば 2 粒子間力の誤差を $1 \%$ 以内に するには, PM 法での格子の大きさを PP 領域を 決める格子の $1 / 13$ 以下にしなければならず, 非常 に多くの PM 格子を必要とする，PM 格子の数を 少なくするには割付計算や差分法に高精度の方法 を導入する必要がある。

割付の高次精度としては 2 次または 3 次のスプ ライン関数がある。 2 次のスプラインでは

$$
f_{\mathrm{e}}=\int S\left(x-x_{i}\right) W\left(x-x_{l}\right) \mathrm{d} x / \Delta
$$




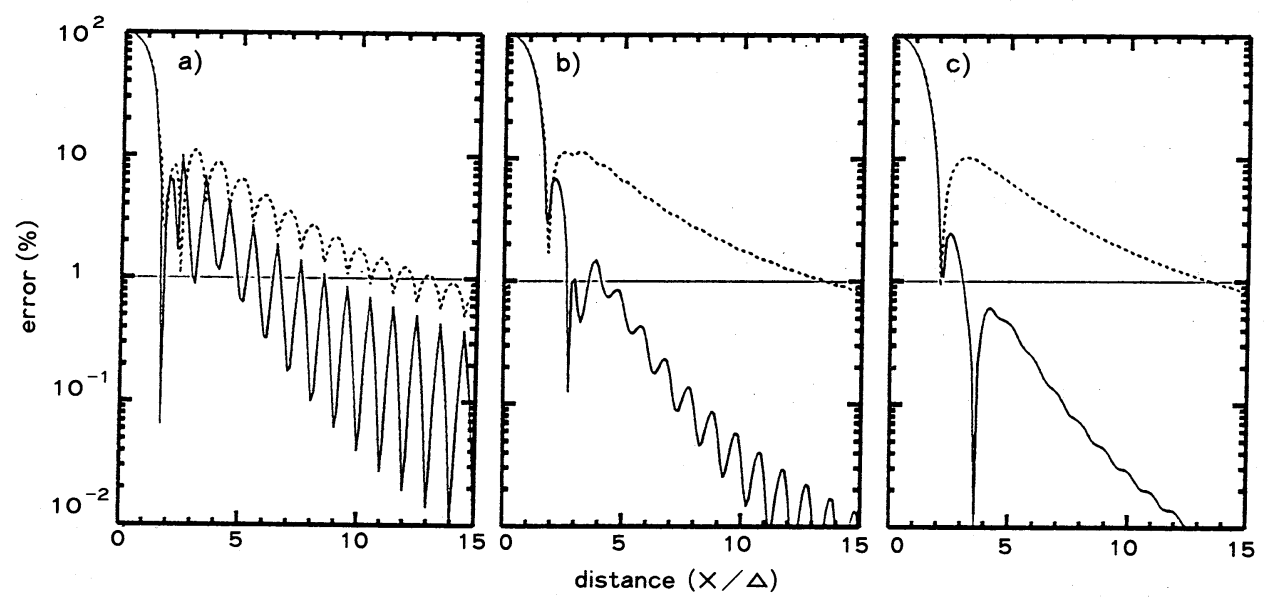

図 3. (a) CIC 法, (b) 2 次スプライン補間, (c) 3 次スプライン補間を用いた場合の粒子間距離と クーロンカの誤差の関係. (a), (b)，（c) とも破線は 2 次差分法, 実線は 4 次差分法の場合 である. 高次スプラインと 4 次差分を併用した場合のみ高精度が保証される.

とすると

$$
\begin{aligned}
f_{l-1} & =\frac{1}{2}\left(\frac{1}{2}-\delta\right)^{2} \\
f_{l} & =\frac{3}{4}-\delta^{2} \\
f_{l+1} & =\frac{1}{2}\left(\frac{1}{2}+\delta\right)^{2}
\end{aligned}
$$

ただし

$$
\delta=\frac{x_{i}-x_{l}}{\Delta}
$$

また， 3 次のスプラインでは，

$$
f_{l-1}=\frac{1}{6}\left(\frac{1}{2}-\delta\right)^{3}
$$

$$
\begin{aligned}
& f_{l}=\frac{1}{2}\left(\frac{1}{2}+\delta\right)^{2}\left(\delta-\frac{3}{2}\right)+\frac{2}{3} \\
& f_{l+1}=-\frac{1}{2}\left(\frac{1}{2}-\delta\right)^{2}\left(\delta+\frac{3}{2}\right)+\frac{2}{3} \\
& f_{l+2}=\frac{1}{6}\left(\frac{1}{2}+\delta\right)^{3} \\
& \delta=\frac{x_{i}-x_{l}}{\Delta}-\frac{1}{2}
\end{aligned}
$$

一方， 4 次の差分法は

$$
\frac{\left.\frac{\partial^{2} \phi}{\partial \Delta^{2}}\right|_{l}=}{\frac{-\phi_{l+2}+16 \phi_{l+1}-30 \phi_{l}+16 \phi_{l-1}-\phi_{l-2}}{12 \Delta^{2}}}
$$

$\frac{\partial \phi}{\left.\partial \Delta\right|_{l}}=\frac{-\phi_{l+2}+8 \phi_{l+1}-8 \phi_{\phi-l}+\phi_{l-2}}{12 \Delta}$ 
となる，図 3 (b)，（c)に2 次のスプライン，およ び 3 次のスプラインを用いた場合についての誤差 を示す。（a)，(b)，(c)図とも，破線は 2 次の差分 法の場合であり，実線は 4 次の差分法の場合であ る。（a）図の実線から明らかなように差分解法のみ 高精度の方法を用いても䛊差の改善は認められな い. (b), (c)の破線から明らかなように高次のスプラ インを用いると格子間隔の整数倍に比例した振動 は減少する。しかし差分法が 2 次精度であれば, スプラインを用いても䛊差は減少しない。（c）の実 線の場合のみ, 距離の 4 乗に比例して誤差が減少 する. 3 次のスプラインと 4 次精度の差分法を用 いた場合には，1\%以内の誤差を得るには格子間 隔で規格化した距離は 3 でよい，従って CIC 法と 比較すると 3 次元の格子数は約 $(3 / 13)^{3} \sim 1 / 81$ と
なる，差分方程式を FFT で解く場合には本質的に は 2 次差分も 4 次差分も計算量は同じであり, 格 子数が十分多ければ格子数に比例する，従って 3 次のスプラインでは CIC 法に比べると計算量が約 $2^{3}=8$ 倍になるが，格子数の減少は割付計算量の 増加を十分補うものである。

$\mathrm{PP}$ 領域内の粒子を除いて PM 法の計算を行う と, PP 領域を決める格子数だけその計算が必要と なり計算量が非常に多くなる。さらに周期境界条 件では特定の PP 領域だけを取り除くのは困難と なる。従って全領域でPM 法の計算を行った後 $\mathrm{PP}$ 領域の粒子による電場を取り除く方が効率が 良い，先に述べた 4 次精度の差分法では，格子点 $\left(l^{\prime}, m^{\prime}, n^{\prime}\right)$ での電荷密度 $\left.\rho l^{\prime}, m^{\prime}, n^{\prime}\right)$ が格子点 $(l$, $m, n)$ 及ぼす電場 $E_{l, m, n}$, は次式で与えられる。

$$
\begin{aligned}
& E_{l, m, n}^{*}=-i \frac{2 \pi \Delta \rho_{l^{\prime}, m^{\prime}, n^{\prime}}}{L^{\prime} M^{\prime} N^{\prime}} \\
& \times \sum_{k_{l}=0}^{\mathrm{L}^{\prime}-1} \sum_{m}^{\mathrm{M}_{\mathrm{m}}^{\prime}-1} \sum_{\sum_{n}=0}^{\mathrm{N}^{\prime}-1} \frac{\exp \left\{\mathrm{i} 2\left(\theta^{\prime}{ }_{l}\left(l-l^{\prime}\right)+\theta_{\mathrm{m}}^{\prime}\left(\mathrm{m}-\mathrm{m}^{\prime}\right)+\theta_{\mathrm{n}}^{\prime}\left(\mathrm{n}-\mathrm{n}^{\prime}\right)\right)\right\}}{\sin ^{2} \theta^{\prime}{ }_{l}\left(1+\frac{1}{3} \sin ^{2} \theta_{l}^{\prime}\right)+\sin ^{2} \theta_{\mathrm{m}}^{\prime}\left(1+\frac{1}{3} \sin ^{2} \theta_{\mathrm{m}}^{\prime}\right)+\sin ^{2} \theta_{\mathrm{n}}^{\prime}\left(1+\frac{1}{3} \sin ^{2} \theta_{\mathrm{n}}^{\prime}\right)} \\
& \times\left\{\sin \theta^{\prime}{ }_{l} \cos \theta_{l}^{\prime}, \quad \sin \theta_{\mathrm{m}}^{\prime}, \quad \cos \theta_{\mathrm{m}}^{\prime}, \sin \theta_{\mathrm{n}^{\prime}} \cos \theta_{\mathrm{n}}^{\prime}\right\}
\end{aligned}
$$

$$
\text { ここで } \theta_{l}^{\prime}=\frac{\pi k_{l}}{L^{\prime}}, \quad \theta_{m}^{\prime}=\frac{\pi k_{m}}{M^{\prime}} \theta_{n}^{\prime}=\frac{\pi k_{n}}{N^{\prime}}
$$

ただし，周期 $L^{\prime} ， M^{\prime}, N^{\prime}$ は考えている系の周期 より十分大きな数を選ばなければならないが，こ れらの計算は 1 回行うだけでよい.

周期境界条件で系の大きさを $L^{3}=4^{3}, \quad P P$ 領域 の大きさを $L_{\mathrm{pp}}^{3}=3^{3}$ とし, PM 法の格子の大きさ が $L_{\mathrm{F}}=\Delta_{\mathrm{PP}} / \Delta_{\mathrm{PM}}=1,2,4$ の場合について電子一イ オン間の力の大きさ（実線と破線）と誤差（1点
鎖点）を $\Delta_{\mathrm{PP}}$ で規格化した距離の関数として評価 したのが図 4 である。ただし，(19)式の， $L^{\prime} ， M^{\prime}$, $N^{\prime}$ は1028とした。

図 4 で破線はPM 法で求まる力であり, 実線は PP 領域に含まれる電荷による電場の除去を行った PPPM 法での力である。この例では, PP格子の セル中心に 1 つの粒子が存在するので PP 領域

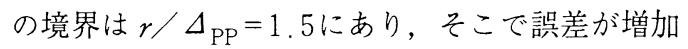
する。 


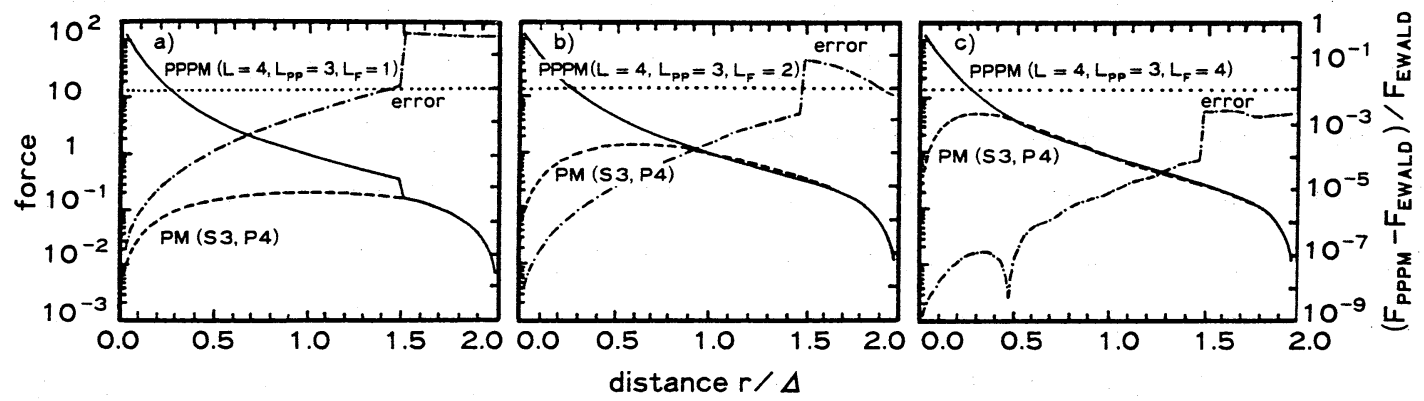

図 4.PM 法の空間格子の大きさと電子一イオン間力（実線, 破線）およびクーロンカとの誤差 (一点鎖線) の関係. (a) , (b), (c) は, それぞれ $\Delta_{\mathrm{PP}} / \Delta_{\mathrm{PM}}=1,2,4$ の場合. $\Delta_{\mathrm{PP}} / \Delta_{\mathrm{PM}}=$ 4 の時, 誤差は全領域で0.5\%以下となる. 破線はPM 法による力, 実線は PPPM 法によ る力，粒子間力は $e^{2} / \Delta^{2}$ で規格化している.

a)
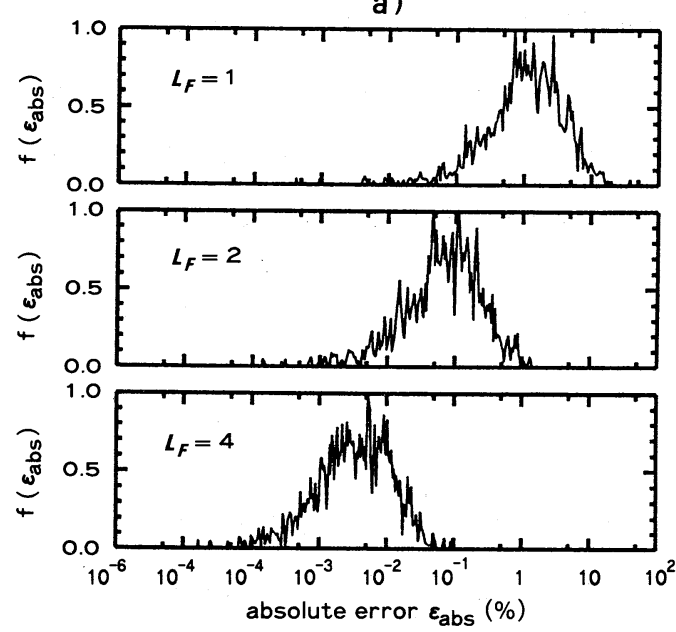

b)
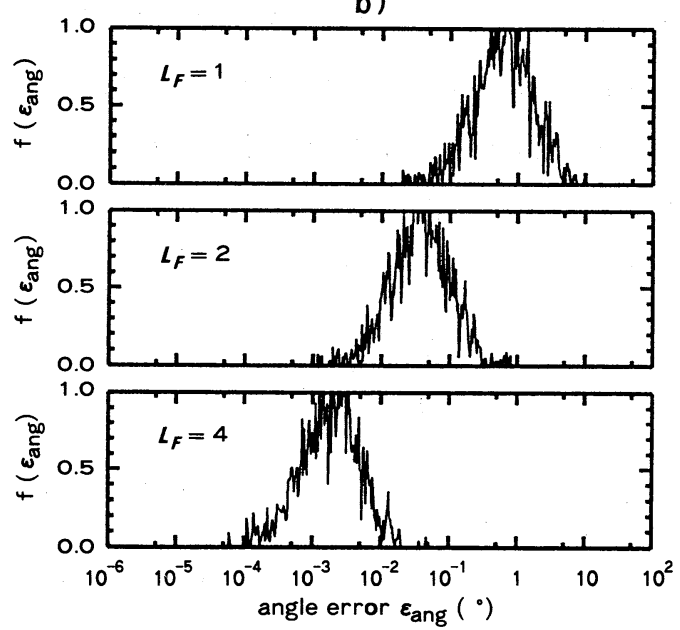

図 5. PPPM 法での粒子間力の絶対値 (a) と角度 (b)の誤差分布. 各図とも上から $L_{F}\left(=\Delta_{\mathrm{PP}} / \Delta_{\mathrm{PM}}\right)=$ $1,2,4$ の場合である.

温度 $13.6 \mathrm{eV}$, 電荷数 $Z=1$ のイオン数密度 $n=$ $5 \times 10^{22} \mathrm{~cm}^{-3}$ の高密度プラズマについて, 電子, イオンの粒子数がそれぞれ500の系で，系の大きさ $\left(L \Delta_{\mathrm{PP}}\right)^{3}=\left(4 \Delta_{\mathrm{PP}}\right)^{3}, \mathrm{PP}$ 領域の大きさを $\left(L_{\mathrm{PP}}\right.$ $\left.\Delta_{\mathrm{PP}}\right)^{3}=\left(3 \Delta_{\mathrm{PP}}\right)^{3}$ とし, $\mathrm{PM}$ 法の格子の大きさが $L_{\mathrm{F}}=\Delta_{\mathrm{PP}} / \Delta_{\mathrm{PM}}=1,2,4$ 場合について, 力の絶対 值と角度の䛊差の分布を調べたのが図 5 である。 図から明らかなように, $L_{\mathrm{F}}=\Delta_{\mathrm{PP}} / \Delta_{\mathrm{PM}}=2$ でも力の 絶対值の誤差は $1 \%$ 以内になる。これは，遠方で
は粒子間力が $r^{-2}$ で減少し，またプラズマでは近 接粒子により電場のシールドを受けるからである。

\section{3. 高密度プラズマの粒子シミュレーション}

「SCOPE」を用いたシミュレーションについて 紹介する。

a）高密度プラズマの制動輻射抑制 ${ }^{9)}$

レーザー核融合プラズマ中の輻射エネルギー輸 送は電子の熱伝導と同様に重要な問題である。高 
密度プラズマ中では，強いクーロン相互作用の結 果, 例えばイオンの囲りの電子や他のイオンを見 い出す確率，すなわち動径分布関数は理想プラズ マと非常に異なったものになる。図 6 はイオン結

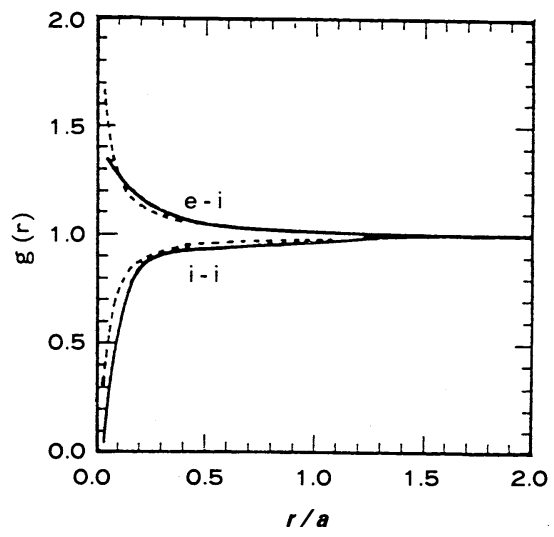

図 6.弱結合プラズマの動径分布関数．イオン結 合係数 $\Gamma=0.0278$, 温度 $1 \mathrm{keV}$ の水素プラス マのイオンーイオン, および電子ーイオン の動径分布関数. 実線はシミュレーション 結果, 破線はRPA 理論値.

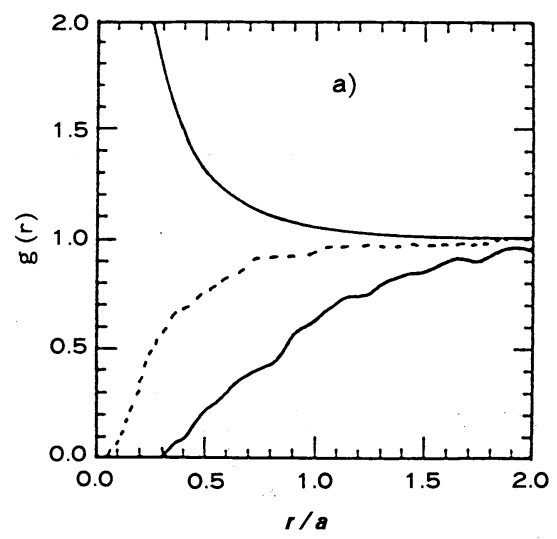

図 7. 強結合プラズマの動径分布関数、水素と炭 素が1対 1 に混合した実効イオン結合係数 $\Gamma_{\mathrm{eff}}=Z_{\mathrm{eff}}^{2} e^{2} / a k T=0.553, \quad\left(Z_{\mathrm{eff}}^{2}=<\right.$ $\left.\left.Z^{-3 / 3}\right\rangle\left\langle Z^{1 / 3}\right\rangle\right)$, 温度 $1 \mathrm{keV} の$ 場合で、炭 素イオンの囲りの炭素イオン（実楾）と水 素イオン (破線) のイオンーイオン動径分 布関数, 電子一イオン動径分布係数（上部 の実線）。
合係数 $\Gamma=0.0278$ (理想プラズマに対応)，温度 $1 \mathrm{keV}$ の水素プラズマのイオンーイオン, 電子ーイ オン動径分布関数をシミュレーションで求めた結 果である。一方，図 7 は水素と炭素が 1 対 1 に混 合した実効イオン結合係数 $\Gamma=Z_{\mathrm{eff}}^{2} e^{2} / a k T=0.553$ $\left.\left(Z_{\text {eff }}^{2}=\left\langle Z^{5 / 3}\right\rangle<Z^{1 / 3}\right\rangle\right)$, の強結合プラズマ での，炭素イオンの囲りの水素イオン，炭素イオ ン，および電子の動径分布関数である。図からも 明らかなように，高密度プラズマでは電子はイオ ンに近づき，イオンは反撥して遠のく。このため イオンの作るポテンシャルは周囲の電子やイオン の分布に強く影響を受け，結果的にはイオンの作 るポテンシャルは遠くには及ばない, 従って, 電 子ーイオン衝突に伴う制動輻射は抑制されること になる10,11).

図 8 に示すように，抑制効果は大きな衝突パラ メーターに起因する比較的低い周波数程著しい.

図は，イオン相関，電子シールド効果が無い場合 の輻射係数で規格化してある．点線はイオン相関

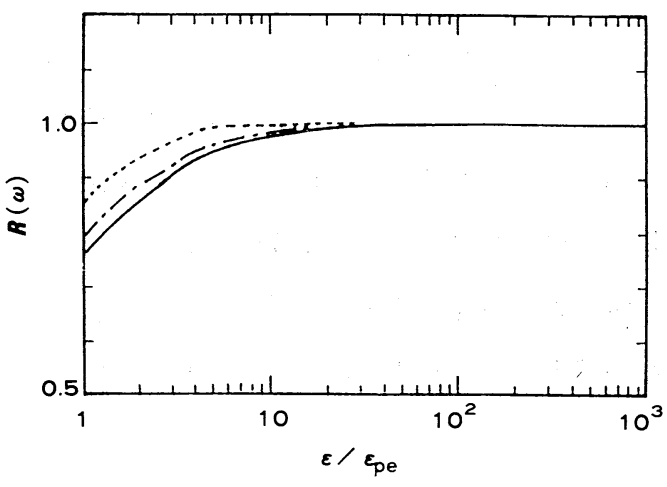

図8，2種イオン混合強結合ブラズマでの制動輻 射の抑制率。破線活イオン相関効果，一点 鎖線は自由電子のシールド効果を含めた湯 合, 実線は束縛電子のシールド効果を含め た場合. 周波数は電子プラズマ周波数で規 格化している。 
による抑制を，一点破線は自由電子シールド効果 を含めたもの, 実線はさらに束縛電子によるシー ルド効果を含めたものである，イオン相関も電子 シールドも同程度の抑制効果を示す。なお，水素 と炭素のイオン混合プラズマでの制動輻射の抑制 率と実効電荷が $\left.\left.Z_{\mathrm{eff}}{ }^{2}=<Z^{5 / 3}\right\rangle<Z^{1 / 3}\right\rangle$ の仮 想的なイオンが存在する場合の抑制率とがほぼ同 じであることも調べられている ${ }^{9)}$.

b ) 固体密度プラズマの非線形 $\mathrm{AC}$ 電気伝導度 ${ }^{12)}$ $100 \mathrm{fs}$ 程度の極超短パルスレーザー光と物質と の相互作用が最近興味を集めている ${ }^{13,14)}$ 。この 様な短いパルスでは，プラズマの膨脹は殆ど無視 でき,レーザー光は固体密度プラズマと直接相互 作用することになる。また，レーザー強度が十分 大きく, 電子の振動速度が熱速度より大きくなる 場合には，電気伝導度は振動速度によって決まる 強い非線形性を示すことになる。この様な大強度 極超短パルスレーザーと物質との相互作用を明ら かにするには，固体密度プラズマの非線形 $\mathrm{AC}$ 電 気伝導度を調べなければならない，図 9 は, 水素 固体プラズマの波長 $0.53 \mu \mathrm{m}$ レーザー光の周波数 に対する $\mathrm{AC}$ 電気伝導度である。横軸は初期熱速 度 $(13.6 \mathrm{eV})$ で規格化した振動速度で, 振動速度 の増加に伴って電気伝導度は減少する. 振動速度 が非常に大きい場合は $\sigma \infty V_{0}^{-3}$ に比例して電気伝 導度が減少することは理論的にも予測されたこと である ${ }^{15,16)}$. 一方 $V_{0} \sim V_{\mathrm{Te}}$ 近傍での理論值との 大きなズレは電子の急激な加熱によるものと考え られる。ちなみに、シミュレーションは約 $10 \mathrm{fs} の$ レーザーパルスを印加した場合に対応しており， 電子はこの短い時間に初期温度の約 5 倍にまで加

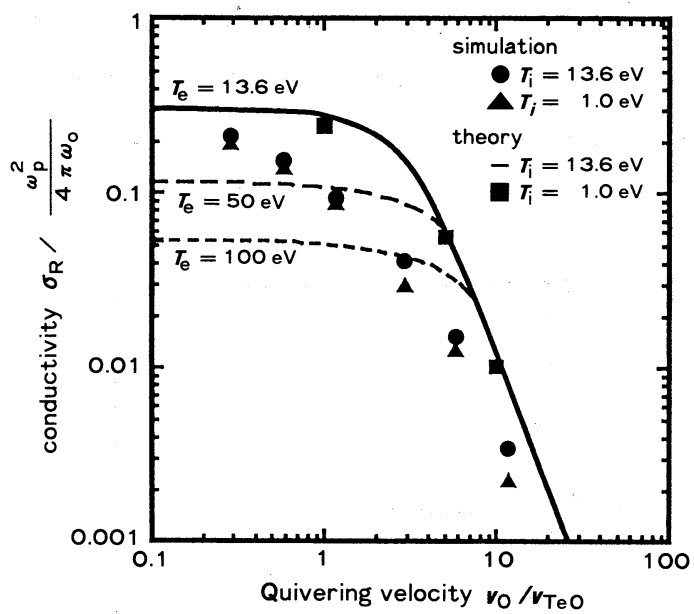

図 9. 固体密度水素プラズマの非線形 $A C$ 電気伝 導度, 横軸は初期熱速度で規格化した電子 の振動速度. 丸と三角が初期温度 $13.6 \mathrm{eV}$, $1 \mathrm{eV}$ のシミュレーション効果. 実線 (13.6 $\mathrm{eV})$ と四角 $(1 \mathrm{eV})$ は, イオン相関と電子 の誘電率を考慮した理論値。
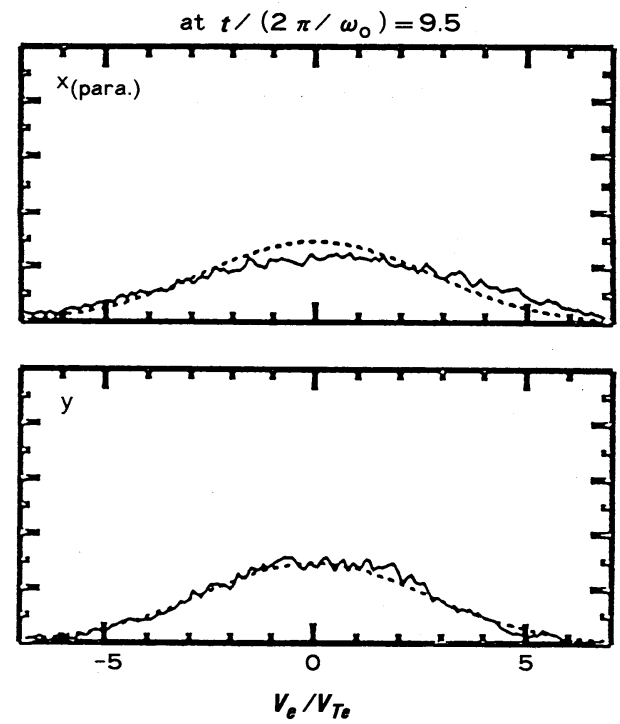

図10. 初期熱速度で規格化した電子の速度分布, 上が電場に平行な成分, 下が垂直成分, 破 線は対応するマクスウェル分布.

熱される。なお $V_{0} \sim 10 V_{\mathrm{Te}}$ での理論値との不一致 はまだ明らかでない，

イオンの加熱はほとんど無視でき, 初期温度に 
よってイオン結合係数は決まっており，初期温度 が低い $(1 \mathrm{eV})$ 場合には, イオン相関が大きく，電 気伝導度は減少する。

電子一電子の衝突は十分大きく, 図10に示すよ うに，印加電場に平行な成分（ $x$ 方向）だけでな く垂直方向にも，ほぼ完全なマクスウェル分布 (破線)に近い速度分布を形成している。

この強い非線形電気伝導度の存在は, レーザー 光により物質を効率よく加熱するには, ある最適 のレーザー光強度が存在することを示唆している. 用いたパラメーターでは $V_{0} \sim 5 V_{\mathrm{Te}}$ の時に，最も

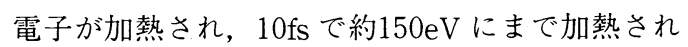
ることがシミュレーションで観測されている.

\section{4.おわりに}

2 成分強結合プラズマのシミュレーションが可 能になったのはスーパーコンピューターの発達に 負うことが大きい。しかし，まだ始まったばかり である。例えば, 散逸を決めるミクロな過程と流 体力学的なマクロな乱れの非線形ダイナミックス 等が, 今後, 計算機の発達と共に可能となってく るだろう。

\section{参考文 献}

1) S. Ichimaru, S. Mitake, S. Tanaka and $X-Z$. Yan : Phys. Rev. A32 (1985) 1768.

2) J.P. Hansen and I. R. McDonald: Phys. Rev. A23 (1981) 2041.

3) C.K. Birdsall and A.B. Laugdon : Plasma Physics via Computer Simulation, (McGraw-Hill, New York, 1985).

4）計算物理と計算化学（海文堂, 田中實, 山本良一 編, 1988).

5) K. Nishihara, H. Furukawa, M. Kawaguchi and Y. Yabe : Japanese Supercomputing (SpringerUerlag, New York, (1988) P.59; K. Nishihara, H. Yasui, M. Kawaguchi and H. Furukawa : (to be published).

6) J.W. Eastwood, R.W. Hockney and O.N. Lawrence : Comput. Phys. Commun. 19 (1980) 215.

7) R.W. Hockeny and J.W. Eastwood : Computer Simulation Using Particles, (Adam Hilger, New York, 1988).

8) C. Deutsch : Phys. Lett. 60A (1977) 317.

9) H. Furukawa and K. Nishihara : Phys. Rev. A42 (1990) 3532.

10) H. Totsuji : Phys. Rev. A32 (1985) 3005.

11) R. Kawakami, K. Mima, H. Totsuji and Y. Yokoyama ; Phys. Rev. A38 (1988) 3618.

12) K. Nishihara and H. Yasui : (to be buplished).

13) H.M. Milckberg, R.R. Freeman and S.C. Davey: Phys. Rev. Lett. 61 (1988) 2364.

14 M.M. Murnane, H.C. Kapteyn and R.W. Falcone : Phys. Rev. Lett. 62 (1989) 155.

15) R.D. Jones and K. Lee : Phys. Fluids 25 (1982) 2307.

16 S. Kato, R. Kawakami and K. Mima : Phys. Rev. A43 (1991) 5560.

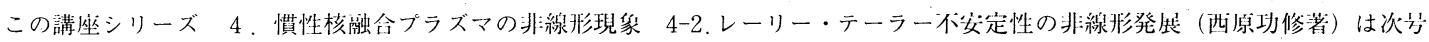
に挒載いたします。 